\title{
Will Corporate Tax Avoidance Lead to Forced Executives Turnover?
}

\author{
Tian Yu \\ School of Management, Jinan University, Guangzhou, China \\ Email: 13170875530@163.com
}

How to cite this paper: Yu, T. (2020). Will Corporate Tax Avoidance Lead to Forced Executives Turnover? American Journal of Industrial and Business Management, 10, 262-285.

https://doi.org/10.4236/ajibm.2020.102017

Received: January 6, 2020

Accepted: February 10, 2020

Published: February 13, 2020

Copyright $\odot 2020$ by author(s) and Scientific Research Publishing Inc. This work is licensed under the Creative Commons Attribution International License (CC BY 4.0).

http://creativecommons.org/licenses/by/4.0/

\section{(c) (i) Open Access}

\begin{abstract}
Based on the data of A-share listed companies in 2004-2018, this paper discusses the possible economic consequences of corporate tax avoidance from the individual level of executives. In this paper, the degree of corporate tax avoidance is divided into aggressive tax avoidance behavior and passive tax avoidance behavior, respectively, to study the impact of different degrees of tax avoidance on executives forced to be replaced by listed companies. It is found that both aggressive tax avoidance and passive tax avoidance will lead to forced executives turnover. In addition, this paper also examines the moderation effects of the nature of property rights, the performance of corporate social responsibility and market concentration on the above-mentioned research, and finds that private companies, companies that perform social responsibility well and companies in areas with fierce market competition, the passive tax avoidance behavior has a greater impact on executives forced turnover.
\end{abstract}

\section{Keywords}

Corporate Tax Avoidance, Executives Turnover

\section{Introduction}

Compared with the developed countries such as Britain, the United States, Germany, France and Japan, the development of China's capital market and financial market is relatively backward. Therefore, difficulties in financing become the main obstacle to the development of listed companies. In order to alleviate the financing pressure of companies, listed companies began to undertake tax avoidance, in order to relieve tax burden for companies and therefore increase the cash retention of companies. According to the statistics of the State Administration of Taxation from 2003 to 2017, China's macro tax burden is about $8 \%$, which is far 
lower than the statutory income tax rate of $25 \%$, indicating that Chinese companies have a common tax avoidance behavior. However, the tax avoidance activities of companies are usually realized through the complex structure and hidden transactions, which increases the information asymmetry between companies, investors and creditors, which will lead to adverse selection and moral hazard. This paper discusses the economic consequences of tax avoidance from the perspective of forced turnover of executives in listed companies.

The decision-making of the appointment and dismissal of executives in Chinese listed companies varies in the nature of the property rights of the company. The appointment and dismissal of executives in state-owned companies are decided by the government, and that of private companies are decided by the board of directors. The above-mentioned decision-making is primarily based on the operating performance of executives in listed companies. In addition to performance, other indicators such as the moral level, social responsibility performance and reputation of executives, also matters. As an important decision for executives, corporate tax avoidance will not only affect the performance of the company, but also affect the external image of both the company and executives. Once the behavior of aggressive tax avoidance of listed companies is exposed by the media, executives will be labeled as "dishonest" by investors, and the corporate image and executives' image will be damaged. At the same time, corporate tax avoidance will result in reformulation the incentive contract for executives, which destroys the original optimal incentive contract. Shareholders need to spend more on supervising the behavior of executives, which greatly increases the internal agency cost of listed companies. Considering the image of executives and internal agency cost, aggressive tax avoidance behavior may lead to mandatory replacement of executives of listed companies. However, under the framework of principal-agent, the ultimate goal of executives is to maximize the wealth of shareholders. Executives who show a passive attitude in tax avoidance activities may be regarded as incompetent. When evaluating the performance of executives, the passive tax avoidance behavior is taken into account, thus passive tax avoidance behavior will also increase the risk of executives forced turnover. There is a great controversy in academia about whether the economic consequences of tax avoidance for companies are positive or passive, so the question still deserves discussion. This paper studies the economic consequences of corporate tax avoidance from the perspective of executives.

This paper is divided into 7 sections. Section 1 describes the purpose and necessity of this study; Section 2 introduces the institutional background of corporate tax avoidance and executive turnover in China; Section 3 infers the hypothesis of this paper; Section 4 is the research design, which constructs the empirical research model of this paper, and explains the data source and relevant variables of this empirical research; Section 5 is the empirical results, verifying the hypothesis of this paper through the data of A-share listed companies, that is, no matter the radical corporate tax avoidance behavior or the negative corporate tax avoidance behavior will cause the executives to be forced replaced; Section 6 is 
the further analysis of this paper, which respectively studies the moderating effect of the nature of property right, the performance of corporate social responsibility and the market competition degree on the above results; Section 7 is the conclusion of this paper. It summarizes the research of this paper and points out the contribution and deficiency of this paper. At the same time, it puts forward the corresponding policy suggestions.

\section{Institutional Background}

\subsection{Background of Tax Avoidance}

China is in the process of economic transformation, developing with a complex and changing macro environment. Compared with the developed European and American markets, the development of China's capital market is relatively backward, and thus the financial market is not enough to meet the financing demands of enterprises, which leads to greater pressure in financing for the Chinese listed companies. According to the World Bank's 2006 survey of global financing market, among 80 countries surveyed, China's listed companies are in the forefront among all, about $75 \%$ of Chinese listed companies attribute the obstructed growth to the financing pressure. In order to alleviate the restriction of insufficient market funds on enterprises' development, many listed companies choose to undertake tax avoidance activities to indirectly increase the cash inflow of enterprises. According to the statistics of 2003-2017, China's macro tax burden is about $8 \%$ (calculated according to the national tax standard), which is far lower than the statutory tax rate of $25 \%$, indicating that there are frequent tax avoidance activities among China's listed companies.

Now the most common way of tax avoidance is through transfer pricing. Listed companies and their related parties sign internal transaction contracts, determine internal transfer prices, and realize transfer profits to avoid tax. Tax avoidance through transfer pricing is more common in multinational enterprises, mainly in two ways: 1) Multinational taxpayers transfer tangible or intangible assets of high tax countries to branches or subsidiaries of tax havens by artificially lower prices, and then sell them at market prices in tax havens, and retain profits in tax havens, so as to enjoy tax-free benefits of tax havens or pay taxes at low rates and avoid high tax burdens. 2) After transferring the assets of a high tax burden country to the branch or subsidiary of B tax haven, the branch or subsidiary of B tax haven will artificially raise the price and transfer it to the branch or subsidiary of C high tax country. In this way, both a and C's profits will be transferred to B's tax haven so as to enjoy tax exemption or pay taxes at a low tax rate, avoid the high tax burden of $\mathrm{A}$ and $\mathrm{C}$, and maximize the profits of multinational taxpayers in terms of total amount. The abuse of transfer pricing to avoid tax transnationally has shaken the stability of the international financial system. In 2009, the G20 summit called on all countries around the world to take action to combat international tax evasion. The Multilateral tax collection Convention came into force in 2011. In 2017, China also began to implement the administrative measures for 
tax related information due diligence regarding to non-resident financial accounts and joined the international anti-tax avoidance organization.

Except for transfer pricing, Chinese listed companies began to weaken their capital in recent years, which has achieved tax avoidance. Capital weakening is to transfer the profits of the profitable enterprises to the related parties through financial expenses by making use of the complicated organizational structure and reaching a capital lending agreement with the related parties. The hidden loan contract constructed by the complex relationship between related parties has brought difficulties to the inspection of tax supervision. Therefore, China has formulated relevant tax regulations on the dismantling of funds between taxpayers. The lending interest between taxpayers is allowed to be deducted before tax according to the amount not higher than the loan interest rate of similar financial institutions and banks in the same period.

In addition, in order to make Chinese enterprises adapt to the changing market environment more quickly, the central government has formulated a series of preferential tax policies. Taking high-tech enterprises as an example, China's preferential tax policies include preferential tax rate (reduce to $15 \%$ of corporate income tax), preferential income from technology transfer (half reduction to transactions more than 5 million), preferential deduction (additional deduction of fixed assets and R\&D expenditure), etc. As a consequence, abusing national tax preference policies has also become a method for Chinese listed companies to avoid tax. By transferring the profits to the enterprises that accessible to the tax preference, the profitable subjects can enjoy the reduced tax burden to the greatest extent.

On the one hand, tax avoidance can alleviate the financing pressure of enterprises, on the other hand, abusing tax avoidance will lead to the unstable financial environment, increase the intensity of tax inspection, and result in the waste of national resources. Therefore, the economic consequences of corporate tax avoidance activities have become a research hotspot of scholars among the world. This paper discusses the influence of corporate tax avoidance in the listed companies from the perspective of the appointment and dismissal of the executives.

\subsection{Background of Executives Forced Turnover}

The appointment and dismissal decisions of Executives in listed companies is a reflect of internal and external corporate governance mechanism to reallocate the owners of corporate power, and it is also one of the most important strategic decisions of enterprises. The form of executives turnover can be divided into departure and succession. This paper will only discuss the situation of executives departure. The departure of executives contains normal departure and abnormal departure. Normal departure refers to executives' retirement, expiration of tenure and other objective reasons. Abnormal departure refers to forced replacement of executives due to subjective reasons, which are usually affected by many factors such as executives' decision-making and corporate performance. This paper obtains the abnormal departure of chairman of the board and chief executive of- 
ficer in Chinese A-share listed companies from 2004 to 2018. According to the results in Table 1, the number of abnormal departures of executives increased from 375 in 2004 to 797 in 2018, with a relatively stable growth rate. By comparing the forced turnover of executives in state-owned and private listed companies, this paper finds that about $60 \%$ of the forced turnover occurs in state-owned companies, which shows that the forced turnover of executives is more frequent in state-owned companies.

The decision-making of the listed companies on the dismissal of executives varies with the nature of property rights. Due to the special background of state-owned enterprises, the appointment and dismissal decisions of executives depend on the government's assessment. A series of performance assessment documents issued by SASAC in 2003 clearly put forward the relation between performance and their appointment; private companies are parallel to state-owned enterprises. So far, a set of formal corporate governance system has been developed, and those systems are applied in the assessment of executives. At present, private companies have formed a set of evaluation system covering financial and non-financial indicators, qualitative and quantitative assessment, and the appointment of executives is no longer dominated merely by operating performance. The accountability system for senior managers of listed companies directly links the operation performance to the appointment and dismissal decision of executives, and implements the accountability procedures for the adverse effects of executives' intentional, negligent or slack manners in listed companies. Generally speaking, no matter

Table 1. Executives forced turnover.

\begin{tabular}{ll}
\hline Year & N \\
\hline 2004 & 375 \\
2005 & 421 \\
2006 & 401 \\
2007 & 404 \\
2008 & 411 \\
2009 & 406 \\
2010 & 450 \\
2011 & 505 \\
2012 & 462 \\
2013 & 571 \\
2014 & 613 \\
2015 & 720 \\
2016 & 758 \\
2017 & 805 \\
2018 & 797 \\
Total & 8099 \\
\hline & \\
\hline & \\
\hline
\end{tabular}


the state-owned or private enterprises, the decision-making of the appointment and dismissal of executives of listed companies is mainly performance-oriented, while non-performance factors will also be taken into consideration. With the growing of the capital market, the requirements of investors for executives of listed companies will be more strict, and the scope of non-performance factors to assess executives will also be expanded in the future.

\section{Hypothesis Development}

According to the principal-agent view of corporate tax avoidance, tax avoidance is a behavior that achieves the purpose of tax burden transfer through a series of complex and hidden transactions. Only the executive knows this process, which intensifies the degree of information asymmetry between the executive and investors, which will lead to adverse selection and moral hazard. In order to reduce the information asymmetry, shareholders need to increase the supervision and control of executive and reduce the probability of self-interest behavior of executive. Moreover, to compensate the extra risk undertaken by executives, shareholders need to restructure compensation contracts, which indirectly destroys the optimal incentive contracts of enterprises (Chen \& Chu, 2005; Desai \& Dharmapala, 2005). The increase of internal agency cost caused by tax avoidance will bring about the concern of shareholders and propose to replace the executive in the shareholders' meeting. In addition, the tax bureau reviews the tax returns of enterprises annually (Ye Kangtao \& Liu Hang, 2014). For enterprises suspected of tax avoidance, the tax bureau will strengthen the inspection of the financial statements of enterprises, which will draw media's attention. Hanlon \& Heitzman (2010) tested the response of investors to corporate tax avoidance activities, and found that the release of corporate tax avoidance news would cause fluctuations in the stock market, specifically the decline of stock price. They provide a possible explanation: if management is willing to cheat the tax bureau, then it is more likely to cheat shareholders. Then it is found that the negative impact of the enterprises with better corporate governance will be reduced. Therefore their reputation will be seriously damaged, forced replacement of executives is exactly a reflection of image damaging.

The cash flow view of corporate tax avoidance believes that corporate tax avoidance activities can reduce the company's actual income tax rate and increase the retained earnings of the company, so that the company has more private capital to arrange future productive activities. Through the case study of 44 tax avoidance enterprises, Graham found that tax avoidance has an impact on debt financing strategies. The debt level of enterprises participating in tax avoidance activities is relatively low, and the debt ratio is about $8 \%$ lower than that of enterprises without tax avoidance (Graham et al., 2017). Wilson (2009) constructed a model of tax avoidance for enterprises, identified the characteristics of tax avoidance enterprises, and pointed out that enterprises implementing tax avoidance usually have large tax differences, and their financial reports will be more radical. He also found that in enterprises with high corporate governance level, 
corporate tax avoidance is a tool to create wealth for shareholders. This is because in enterprises, tax avoidance is usually realized by means of wealth transfer. The increase of "cash flow" has eased the financing pressure of the enterprise and can reduce the financing cost of the enterprise. Liu \& Lv (2018) analyzed A-share listed companies and found that for every $1 \%$ increase in tax avoidance degree of enterprises compared with competitors, the market share of the industry will increase by $1.9 \%$ in the future, which means that tax avoidance can help enterprises establish competitive advantages. Zhang et al. (2018) found that when the financing constraints were serious, the management would take measures to reduce the cash outflow to relieve the financing pressure. Tax avoidance, as a reduction of cash outflow, was often used by the management. Wang \& Luo (2017) found that corporate social responsibility, as a risk hedging mechanism for tax avoidance, prolonged the period of corporate value promotion by corporate tax avoidance, while corporate tax avoidance made up for the lag risk of corporate social responsibility for value promotion. The complementary effect of corporate tax avoidance and corporate social responsibility not only brings short-term value to the company, but also brings long-term sustainable value. Under the principal-agent framework, the ultimate goal of the company is to maximize shareholder wealth. The cash flow effect of tax avoidance activities can help executive achieve this goal, and shareholders will also expect executives to make decisions that maximize their benefits. When executive refuses or passively implements tax avoidance activities, it will be deemed incompetent by shareholders and fail to perform its fiduciary duties. In the evaluation of executive performance, passive tax avoidance is considered as a poor performance of the CEO, and the result of which may be forced replacement by the company.

Therefore, under the comprehensive consideration of the principal-agent and cash-flow view of corporate tax avoidance, this paper believes that both the aggressive tax avoidance activities and the passive tax avoidance activities of enterprises will lead to executives forced turnover. Based on this, the following hypothesis is made:

Hypothesis 1: Both aggressive tax avoidance and passive tax avoidance by executives increase the probability of executives' forced turnover.

In addition to being responsible for the performance of listed companies, executives of state-owned enterprises also undertake other political tasks. The strategy of state-owned enterprises is closely related to local economy controlled by the government. Therefore, compared with private enterprises, state-owned enterprises have more extensive assessment criteria for executives. In addition, due to the special property rights of state-owned enterprises, the principal-agent problem is not as serious as that of private enterprises. Therefore, compared with private enterprises, the aggressive tax avoidance behavior of state-owned enterprises will not lead to a significant increase in the internal agent costs. Based on this, this paper infers that, compared with private enterprises, the aggressive tax avoidance of state-owned Listed Companies has a lower impact on the mandatory replacement of executives. 
Besides, according to Wang \& Luo (2017), corporate social responsibility and corporate tax avoidance have complementary effects. Corporate tax avoidance will increase short-term business performance and damage long-term value, while the performance of social responsibility makes up for the risk of damaging long-term value resulting from corporate tax avoidance. The executives who has fulfilled the corporate social responsibility well pays more attention to the long-term development of the enterprise, so it is less likely to adopt the behavior of tax avoidance to adjust the profits of the enterprise. In addition, the management who has fulfilled the social responsibility can also convey a positive signal to the shareholders and the outside world. Under the reputation mechanism, the risk of management being forced to change is lower.

Liu \& Lv (2018) found that for every $1 \%$ increase in the degree of corporate tax avoidance, the market share of Listed Companies in the industry will increase by $1.9 \%$, indicating that corporate tax avoidance can improve the competitiveness of listed companies. In areas with low market concentration, the competition between listed companies is more intense. Tax avoidance is also a means to enhance the competitiveness of listed companies. Therefore, negative tax avoidance will lead to the decline of competitiveness of enterprises, and enterprises will take measures to force the replacement of executives.

Based on this, hypothesis 2 is made:

Hypothesis 2a: Compared with the private enterprises, aggressive tax avoidance of the listed companies in the state-owned enterprises has a lower impact on the mandatory turnover of executives.

Hypothesis 2b: For enterprises that have performed their social responsibilities well, aggressive tax avoidance behavior of listed companies has a lower impact on the mandatory turnover of executives.

Hypothesis 2c: In areas with fierce competition, passive tax avoidance is more likely to result in forced turnover of executives.

\section{Data and Methodology}

\subsection{Empirical Strategy}

In order to test the impact of aggressive tax avoidance activities and passive tax avoidance activities on the mandatory replacement of listed company executives, this paper uses the industry standardized effective tax rate and the difference between the industry standardized nominal tax rate and the effective tax rate to perform a logistic regression on the mandatory replacement of listed company executives. Therefore we build the following logistic regression models (1) and (2):

$$
\begin{aligned}
& \operatorname{Logit}\left(\mathrm{f} \_\mathrm{CEO} \_\mathrm{fturnover}\right)=\alpha \text { highETR }+\beta \text { lowETR }+\gamma \text { Controls }+\varepsilon \\
& \text { Logit }\left(\mathrm{f} \_\mathrm{CEO} \_\mathrm{fturnover}\right)=\alpha \text { highRATE }+\beta \text { lowRATE }+\gamma \text { Controls }+\varepsilon
\end{aligned}
$$

Among them, f_CEO_fturnover is the proxy of mandatory turnover for the next period. If a forced CEO turnover occurs in the next period, then $\mathrm{f}$ _CEO_fturnover $=1$; otherwise, or f_CEO_fturnover $=0$. This paper defines the executives of listed companies as the chairman of the board and chief executive officer of the 
company. In addition, the turnover of executives of listed companies is divided into voluntary turnover and mandatory turnover. This paper only considers the mandatory turnover of executives, because only the mandatory turnover of executives is related to their corporate decisions. Turnover due to objective reasons or the expiration of their term cannot reflect the decision-making role of executives and the governance role of external investors. Therefore, this paper classifies changes due to job transfers, resignations, dismissals, and personal reasons as mandatory turnover.

This paper divides effective tax rate (ETR) after normalization into five quantiles. When ETR is at the highest level (5th quantile), higher $=1$, which means that the gap between the effective tax rate and the industry average tax rate is the smallest, and executives engaged in passive tax avoidance; when the effective tax rate ETR is at the lowest level (1st quantile), lowETR $=1$, which means that the gap between the effective tax rate and the industry average tax rate is the largest, and executives engaged in aggressive tax avoidance. Similarly, the difference between the nominal tax rate and the effective tax rate after the industry standardization (RATE) is divided into 5 equal parts. When RATE is at the highest level ( 5 th quantile), then highRATE $=1$, which means that the difference between the nominal tax rate and the effective tax rate is the largest, and executives engaged in aggressive tax avoidance; when the rate is at the lowest level (1st quantile), then lowRATE $=1$, which means that the difference between the nominal tax rate and the effective tax rate is the smallest, and executives engaged in passive tax avoidance.

The control variables refer to the research of Gallemore et al. (2014), including size (measured by the logarithm of total assets of listed companies), financial leverage (measured by the proportion of interest bearing liabilities of listed companies to total assets), operating performance (dsales, droa, measured by the ratio of sales revenue to total assets and the difference in return on asset), ownership (take 1 for state-owned companies and 0 for private companies), duality (whether the CEO and the chairman of the board of directors are held by the same person, take 1 if yes and 2 otherwise), meat or beat analyst forecast (meat_beat, take 1 for reaching the analyst forecast, 0 otherwise).

\subsection{Data and Variables}

All A-share listed companies from 2004 to 2018 are selected as the initial research samples, and the initial samples are processed in the following ways: 1) ST listed companies are excluded; 2) financial companies under the industry classification of CSRC 2012 are excluded; 3) listed companies with missing financial data are excluded; a total of 3521 samples of listed companies and 17,761 observations are obtained.

The financial data and executive turnover data of Listed Companies in this paper are from CSMAR database, the data of tax supervision intensity are from China Statistical Yearbook, and the data of nominal income tax rate and beta value are from Wind database. Corporate social responsibility data comes from 
Runling Global Social Responsibility Report. In this paper, Stata14 software is used for data processing and analysis. In order to eliminate the influence of outliers on the research results, $1 \%$ and $99 \%$ winsorize of continuous variables were used in this paper.

This paper starts with the descriptive statistics of the forced turnover of executives, and analyzes the situation of the forced turnover of executives of Listed Companies in 2004-2018. As seen in Table 2, except year 2012, the number of forced turnover of executives is rising annually, and in all, 8099 of the forced turnover took place in 2004-2018. Secondly, in order to strengthen the understanding of key variables, this paper describes variables from the aspects of mean, standard deviation, maximum, median and minimum. From the results established in Table 3, about $17.5 \%$ executives are forced replaced in the next period; the mean value of ETR and RATE is 0, and it can be seen that the maximum and minimum values of tax avoidance proxy differs greatly, showing a polarization state, indicating that some listed companies are undertook passive tax avoidance, while others undertook aggressive tax avoidance. The mean value of ownership in the control variable is 0.522 , which indicates that about half of the companies in the sample are state-owned enterprises, and the mean value of duality is 1.801, indicating that some chairman hold the position of CEO at the same time, and the mean value of meat_beat is 0.24 , which indicates that about $24 \%$ of the companies have reached the analysts' forecast.

Table 2. Variable description.

\begin{tabular}{|c|c|}
\hline Variable name & Variable description \\
\hline f_CEO_fturnover & $\begin{array}{l}\text { Forced turnover of executives in the next period. If there is a forced turnover } \\
\text { among chairman or CEO, then take } 1 ; 0 \text { otherwise }\end{array}$ \\
\hline ETR & $\begin{array}{l}\mathrm{ETR}=\text { Average value of (income tax expense }- \text { deferred income tax } \\
\text { expense)/profit before tax after industry standardization in the previous } \\
\text { three years } \\
\text { ETR is further divided into high ETR and low ETR, which represent passive } \\
\text { tax avoidance and aggressive tax avoidance by taking the } 5^{\text {th }} \text { quantile and } 1^{\text {th }} \\
\text { quantile respectively }\end{array}$ \\
\hline RATE & $\begin{array}{l}\text { RATE = nominal income tax rate }- \text { ETR } \\
\text { RATE is further divided into highRATE and lowRATE, represent aggressive } \\
\text { tax avoidance and passive tax avoidance respectively }\end{array}$ \\
\hline Size & Logarithm of total assets \\
\hline Leverage & Long term loan/total assets \\
\hline dsales & $\begin{array}{l}\text { (sales revenue of current period - sales revenue of previous period)/total } \\
\text { assets of previous period }\end{array}$ \\
\hline $\mathrm{dROA}$ & $\begin{array}{l}\text { (net profit of current period - net profit of previous period)/total assets of } \\
\text { previous period }\end{array}$ \\
\hline Ownership & 1 for state-owned companies and 0 for private companies \\
\hline Duality & $\begin{array}{l}\text { whether the CEO and the chairman of the board of directors are held by the } \\
\text { same person, take } 1 \text { if yes and } 2 \text { otherwise }\end{array}$ \\
\hline Meat_beat & take 1 for reaching the analyst forecast, 0 otherwise \\
\hline
\end{tabular}


Table 3. Statistical descriptions.

\begin{tabular}{ccccccc}
\hline & $\mathrm{N}$ & Mean & St.Dev & Max & Median & Min \\
\hline f_CEO_fturnover & 17,761 & 0.175 & 0.38 & 1 & 0 & 0 \\
ETR & 17,761 & 0.003 & 0.982 & 26.929 & 0.016 & -37.986 \\
RATE & 17,761 & 0 & 0.994 & 27.741 & 0.097 & -35.224 \\
size & 17,759 & 22.068 & 1.361 & 28.509 & 21.922 & 11.348 \\
leverage & 16,841 & 0.075 & 0.105 & 0.846 & 0.027 & 0 \\
dsales & 17,722 & 0.067 & 0.314 & 7.376 & 0.05 & -19.539 \\
dROA & 17,759 & -0.79 & 106.748 & 169.279 & 0.004 & -14200 \\
ownership & 17,758 & 0.522 & 0.5 & 1 & 1 & 0 \\
duality & 17,416 & 1.801 & 0.399 & 2 & 2 & 1 \\
meat beat & 15,037 & 0.24 & 0.427 & 1 & 0 & 0 \\
\hline
\end{tabular}

Finally, this paper divides the degree of corporate tax avoidance into five quantiles, and makes a descriptive analysis of the probability of forced turnover of executives in each quantile. According to the results of Figure 1, it can be seen that the probability of forced turnover of executives in listed companies is $\mathrm{U}$-shaped with that of corporate tax avoidance, that is, whether the degree of tax avoidance is very high or very low, the probability of forced turnover of executives is both very high, while the probability of forced turnover is relatively low when the degree of tax avoidance is at a moderate level The descriptive statistical figures provide an initial evidence for Hypothesis 1.

In addition, this paper also tests the correlation of all variables. According to the test results in Table 4, in general, the effective tax rate ETR has nothing to do with the forced turnover of executives. Therefore, in logit regression, it is necessary to distinguish the high and low degree of tax avoidance and test the probability of forced turnover of executives respectively. RATE is passively related to the executive forced turnover, with a correlation coefficient of -0.041 , which is significant at the level of $1 \%$, indicating that the lower the degree of corporate tax avoidance is, the higher the probability of executive forced turnover is. Combined with the analysis of the results in Figure 1, the possible explanation is that passive tax avoidance has a more obvious effect on executive forced turnover. Other control variables such as leverage, dsales, ownership, duality, and meat-beat are all significantly related to the explanatory variables, indicating that the higher the leverage, the greater the risk faced by the enterprise, the higher the probability of executives being forced to replace; the higher the income growth rate, the lower the probability of executives being forced to replace; more executives being forced to replace in state-owned enterprises; CEO duality is less likely to be force replaced; executives meeting analysts' forecast is less likely to be forced replaced. 

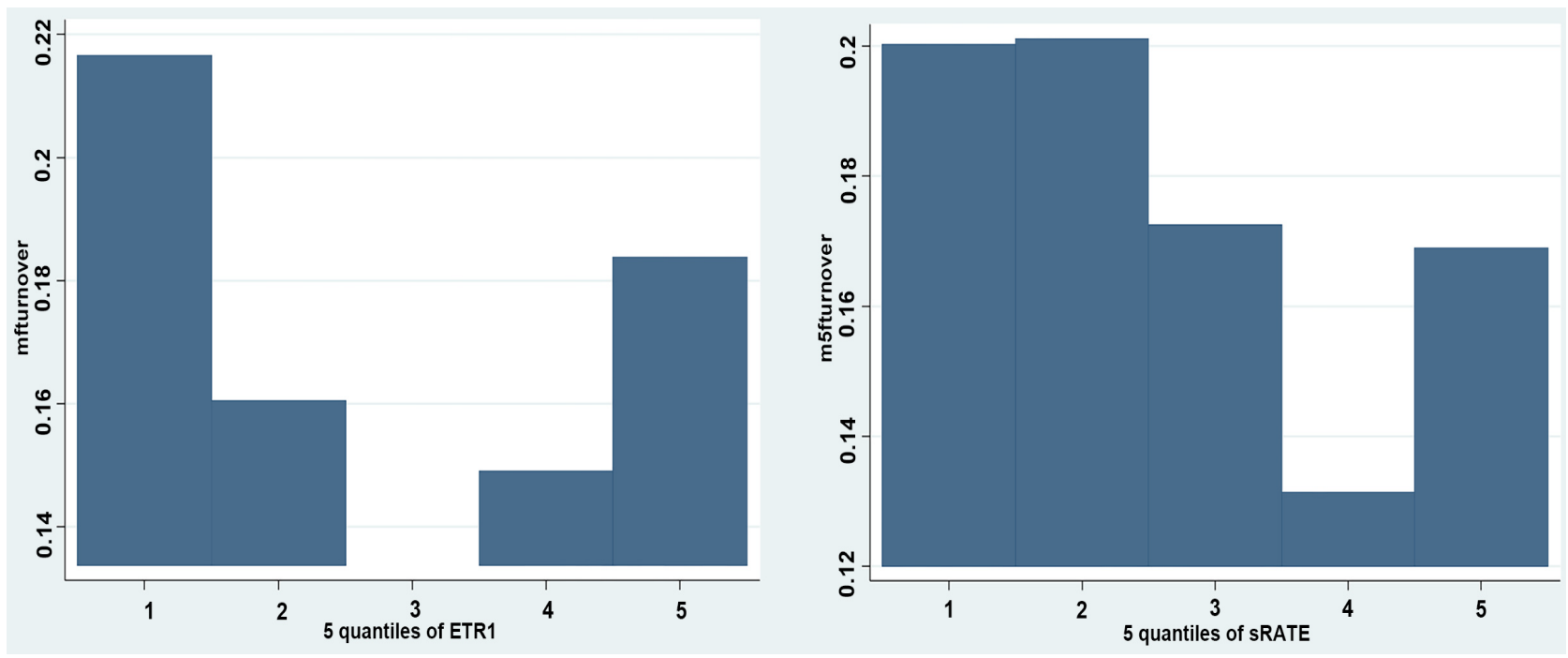

Figure 1. Executives forced turnover and corporate tax avoidance.

Table 4. Correlation of variables.

\begin{tabular}{|c|c|c|c|c|c|c|c|c|c|c|}
\hline Variables & (1) & (2) & (3) & (4) & (5) & (6) & (7) & (8) & (9) & (10) \\
\hline (1) f_CEO_fturnover & 1.000 & & & & & & & & & \\
\hline (2) ETR & -0.017 & 1.000 & & & & & & & & \\
\hline (3) RATE & $-0.041^{\star}$ & $0.420^{*}$ & 1.000 & & & & & & & \\
\hline (4) size & 0.010 & 0.014 & $-0.031^{\star}$ & 1.000 & & & & & & \\
\hline (5) leverage & $0.026^{*}$ & 0.004 & $-0.026^{*}$ & $0.437^{*}$ & 1.000 & & & & & \\
\hline (6) dsales & $-0.023^{\star}$ & 0.012 & $0.020^{*}$ & $0.069^{*}$ & $-0.029^{*}$ & 1.000 & & & & \\
\hline (7) dROA & 0.003 & 0.002 & 0.002 & $0.059^{*}$ & 0.005 & $-0.124^{*}$ & 1.000 & & & \\
\hline (8) ownership & $0.104^{*}$ & 0.003 & $-0.040^{*}$ & $0.236^{*}$ & $0.171^{*}$ & $-0.021^{*}$ & 0.008 & 1.000 & & \\
\hline (9) duality & $0.092^{*}$ & 0.002 & -0.019 & $0.107^{*}$ & $0.098^{\star}$ & 0.003 & -0.004 & $0.257^{*}$ & 1.000 & \\
\hline (10) meat_beat & $-0.021^{\star}$ & 0.009 & -0.014 & $0.106^{*}$ & 0.010 & $0.206^{*}$ & $0.166^{*}$ & $0.091^{*}$ & $0.045^{*}$ & 1.000 \\
\hline
\end{tabular}

*: Shows significance at the 0.01 level.

\section{Empirical Results}

In the Model (1), the coefficients of highETR and lowETR are significantly positive, which shows that the probability of executives being forced to replace is significantly increased under the passive tax avoidance and aggressive tax avoidance, respectively supporting the cash flow view and principal-agent view. Under cash flow view, corporate tax avoidance increases shareholders' wealth through the saved cash flow, and passive tax avoidance is regarded as incompetence of executives under the fiduciary responsibility, and executives are claimed to be forced replaced on the shareholders' meeting. Under principal-agent view and executive reputation view, corporate tax avoidance increases the potential agency cost, and the executives is also labeled "dishonest" due to the publicity of tax 
avoidance behavior. If the agency cost increases and the reputation of executives is damaged, enterprises will take measures to force the replacement of executives.

In the Model (2), the coefficient of highRATE is significantly positive, indicating that aggressive tax avoidance will increase the probability of executives being forced to replace, and the coefficient of lowRATE is also significantly positive, indicating that passive tax avoidance will increase the probability of executives being forced to replace. All the regression results in this paper control the fixed effect of industry and year, and use robust to adjust the standard error. The regression results of Hypothesis 1 are shown in Table 5.

According to the results of Table 5, it can be found that the coefficient of ETR is -0.043 , which is significantly passive at the level of $10 \%$, indicating that for every $1 \%$ increase in effective tax rate, the probability of executives' forced turnover decreases by $24.6 \%(-0.043 / 17.46 \%)$, and the coefficient of RATE is -0.084 , which is significantly passive at the level of $1 \%$, indicating that for every $1 \%$ increase in the difference between nominal tax rate and effective tax rate, the probability of executives' forced turnover decreased by $48.1 \%(-0.084 / 17.46 \%)$. Furthermore, the degree of corporate tax avoidance is further divided into two categories: aggressive tax avoidance (lowETR, highRATE) and passive tax avoidance (highETR, lowRATE). The results show that aggressive tax avoidance is significantly positive at the level of $1 \%$ when measured by effective tax rate, but not significant when measured by the difference between nominal tax rate and effective tax rate; passive tax avoidance is significantly positive at the level of $5 \%$ and $1 \%$ respectively. The above results show that whether the corporate adopts too aggressive tax avoidance strategy or too passive tax avoidance strategy, the risk of executives being forced to replace will increase.

Among the control variables, property rights, CEO duality and whether it meets the analyst's forecast will significantly affect the probability of executives being forced to replace. The results show that the probability of executives being replaced in state-owned enterprises is significantly higher than that in private enterprises. This may be because the assessment standard of state-owned enterprises for executives is not only corporate performance, but also political performance. The appointment decisions of executives are interfered by State-owned Assets Supervision and Administration Commission (SASAC), causing higher uncertainty of executives, thus the rate of executive turnover of state-owned enterprises is higher than that of private enterprises. In an enterprise where the chairman holds the position of CEO, due to highly concentrated power, the chairman is has a discursive power on the board, so the probability of forced turnover of the chairman is lower than that of the enterprise where the two positions are not integrated. In addition, meeting the analyst forecast can reduce the risk of executives being replaced to a large extent. As an external governance mechanism, analyst forecast can play a role of supervision and incentive for executives. 
Table 5. Regression results of corporate tax avoidance and executives forced turnover.

\begin{tabular}{|c|c|c|c|c|}
\hline \multicolumn{5}{|c|}{ Regression Results } \\
\hline & \multicolumn{2}{|c|}{ ETR } & \multicolumn{2}{|c|}{ RATE } \\
\hline & f_CEO_fturnover & f_CEO_fturnover & f_CEO_fturnover & f_CEO_fturnover \\
\hline \multirow[t]{2}{*}{ ETR } & $-0.043^{*}$ & & & \\
\hline & $(-1.64)$ & & & \\
\hline \multirow[t]{2}{*}{ highETR } & & $0.146^{\star *}$ & & \\
\hline & & $(2.01)$ & & \\
\hline \multirow[t]{2}{*}{ lowETR } & & $0.350^{* * *}$ & & \\
\hline & & $(4.73)$ & & \\
\hline \multirow[t]{2}{*}{ RATE } & & & $-0.084^{* * *}$ & \\
\hline & & & $(-3.16)$ & \\
\hline \multirow[t]{2}{*}{ highRATE } & & & & 0.028 \\
\hline & & & & $(0.40)$ \\
\hline \multirow[t]{2}{*}{ lowRATE } & & & & $0.184^{* * *}$ \\
\hline & & & & $(2.65)$ \\
\hline \multirow[t]{2}{*}{ size } & -0.012 & -0.010 & -0.019 & -0.015 \\
\hline & $(-0.55)$ & $(-0.46)$ & $(-0.84)$ & $(-0.68)$ \\
\hline \multirow[t]{2}{*}{ leverage } & 0.199 & 0.158 & 0.202 & 0.190 \\
\hline & $(0.76)$ & $(0.60)$ & $(0.77)$ & $(0.73)$ \\
\hline \multirow[t]{2}{*}{ dsales } & -0.137 & -0.119 & -0.128 & -0.123 \\
\hline & $(-1.04)$ & $(-0.91)$ & $(-0.97)$ & $(-0.93)$ \\
\hline \multirow[t]{2}{*}{$\mathrm{dROA}$} & -0.121 & -0.117 & -0.121 & -0.123 \\
\hline & $(-0.53)$ & $(-0.53)$ & $(-0.54)$ & $(-0.54)$ \\
\hline \multirow[t]{2}{*}{ ownership } & $0.499^{* * *}$ & $0.493^{* * *}$ & $0.492^{* * *}$ & $0.493^{* * *}$ \\
\hline & $(9.18)$ & $(9.05)$ & $(9.04)$ & $(9.06)$ \\
\hline \multirow[t]{2}{*}{ duality } & $0.583^{* * *}$ & $0.587^{\star * *}$ & $0.582^{* * *}$ & $0.580^{* * *}$ \\
\hline & $(8.08)$ & $(8.13)$ & $(8.06)$ & $(8.05)$ \\
\hline \multirow[t]{2}{*}{ meat_beat } & $-0.204^{* * *}$ & $-0.189^{* * *}$ & $-0.204^{* * *}$ & $-0.202^{\star * *}$ \\
\hline & $(-3.45)$ & $(-3.20)$ & $(-3.46)$ & $(-3.43)$ \\
\hline Industry & Control & Control & Control & Control \\
\hline Year & Control & Control & Control & Control \\
\hline \multirow[t]{2}{*}{ _cons } & $-2.727^{\star * \star}$ & $-3.065^{* * *}$ & $-2.588^{* * *}$ & $-2.759^{* * *}$ \\
\hline & $(-5.28)$ & $(-5.88)$ & $(-5.01)$ & $(-5.30)$ \\
\hline $\mathrm{N}$ & 13,943 & 13,943 & 13,943 & 13,943 \\
\hline
\end{tabular}

$\mathrm{t}$ statistics in parentheses: " $p<0.1 ;{ }^{* *} p<0.05 ;{ }^{* * *} p<0.01$ ".

\section{Further Analysis}

1) Moderating effect of property rights 
This paper further discusses whether the nature of property rights affects the effect of corporate tax avoidance on the forced turnover of executives. The results in Table 6 verify the above inference. In private enterprises, the coefficient of lowETR is 0.680 , which is significantly positive at the level of $1 \%$ ( $t$ value is 5.12 ), in state-owned enterprises, which is 0.190 , which is significantly positive at the level of $1 \%$ ( $t$ value is 2.16). In this paper, the suest test is carried out for two groups of samples. The test results show that the difference of coefficient of lowETR in the logit regression between the two groups is significant at the level of $1 \%$. The value of $\mathrm{Chi}^{2}$ is 8.71 , which proves that the nature of property rights can moderate the relation between corporate tax avoidance and executive forced turnover. Because of its special property rights and diversified assessment standards, state-owned enterprises can weaken the risk of executive mandatory replacement brought by aggressive corporate tax avoidance.

2) Moderating effect of corporate social responsibility

This paper examines whether the performance of corporate social responsibility affects the risk of forced turnover caused by executives' aggressive tax avoidance or passive tax avoidance. This paper obtained the social responsibility report disclosed by Runling global in 2009-2017. Limited by the scope of statistics, this report only disclosed the corporate social responsibility performance of 795 listed companies, so this paper only tested the corporate social responsibility impact of the 795 listed companies. In this paper, the rating level in the report is taken as the proxy of corporate social responsibility. The firm-years whose rating level is higher than the median are defined as performing corporate social responsibility well, and the firm-years whose rating level is lower than the median are defined as performing corporate social responsibility poor. We conduct logit regression for the above two groups.

According to the results in Table 7, the group with poor performance of corporate social responsibility, the coefficient of highETR is 0.054 , which is significantly positive at the level of $5 \%$, and the coefficient of lowETR is -0.020 , which is not significant, which indicates that passive tax avoidance will increase the probability of forced replacement of executives in listed companies, while aggressive tax avoidance has no impact on the replacement of executives. In the group with well performance of corporate social responsibility, the coefficient of highETR was -0.016 , which is not significant. In addition, suest test is used to check the difference between two groups. The coefficients of highETR in the two groups were significantly different at the level of $5 \%\left(\mathrm{Chi}^{2}=4.14\right)$, while the coefficients of lowETR make no difference. The above results show that in the listed companies that have better fulfilled their social responsibilities, the impact of passive tax avoidance on the forced turnover of executives is weakened, which reflects that the listed companies which have fulfilled their corporate social responsibilities pay less attention to short-term business performance, while more attention to the long-term value of the enterprise. On the other hand, it provides extra evidence for the research of Wang \& Luo (2017) that corporate social responsibilities helps to improve the long-term value of the company. 
Table 6. Moderating effect of property rights.

\begin{tabular}{|c|c|c|}
\hline \multicolumn{3}{|c|}{ Regression Results } \\
\hline & Private & State-owned \\
\hline & f_CEO_fturnover & f_CEO_fturnover \\
\hline \multirow[t]{2}{*}{ highETR } & 0.208 & 0.103 \\
\hline & $(1.56)$ & $(1.19)$ \\
\hline \multirow[t]{2}{*}{ lowETR } & $0.680^{* * *}$ & $0.190^{* \star}$ \\
\hline & $(5.12)$ & $(2.16)$ \\
\hline \multirow[t]{2}{*}{ size } & $-0.102^{\star *}$ & 0.014 \\
\hline & $(-2.27)$ & $(0.56)$ \\
\hline \multirow[t]{2}{*}{ leverage } & $1.102^{* *}$ & -0.134 \\
\hline & $(2.16)$ & $(-0.44)$ \\
\hline \multirow[t]{2}{*}{ dsales } & -0.022 & -0.125 \\
\hline & $(-0.10)$ & $(-0.83)$ \\
\hline \multirow[t]{2}{*}{ dROA } & -0.112 & -0.004 \\
\hline & $(-0.49)$ & $(-0.01)$ \\
\hline \multirow[t]{2}{*}{ duality } & $0.667^{* * *}$ & $0.438^{* * *}$ \\
\hline & $(6.98)$ & $(3.93)$ \\
\hline \multirow[t]{2}{*}{ meat_beat } & $-0.286^{\star * *}$ & $-0.151^{\star *}$ \\
\hline & $(-2.66)$ & $(-2.08)$ \\
\hline Industry & Control & Control \\
\hline Year & Control & Control \\
\hline \multirow[t]{2}{*}{ _cons } & -1.439 & $-2.645^{\star * *}$ \\
\hline & $(-1.41)$ & $(-4.17)$ \\
\hline $\mathrm{N}$ & 6583 & 7353 \\
\hline
\end{tabular}

$\mathrm{t}$ statistics in parentheses: “* $p<0.1 ;{ }^{* *} p<0.05 ;{ }^{* *} p<0.01$ ”.

\section{3) Moderating effect of product market centralization}

This paper further discusses whether the centralization of the product market can play a regulatory role in the turnover of executives brought about by corporate tax avoidance. According to the regression results of this paper (Table 8), the coefficient of highETR is 0.152 in the group with high product market centralization, which is significant at the level of $10 \%$; in the group with low product market centralization, the coefficient of highETR is 0.226 , which is significant at the level of $5 \%$. The above results show that compared with the group with high market centralization, enterprises under low market centralization are more likely to take forced replacement measures for executives due to their passive tax avoidance behavior. This is because in areas with low market concentration, the competition between 
Table 7. Moderating effect of corporate social responsibility.

\begin{tabular}{|c|c|c|}
\hline \multicolumn{3}{|c|}{ Regression Results } \\
\hline & CSR_DUM = 1 & CSR_DUM $=0$ \\
\hline & f_CEO_fturnover & f_CEO_fturnover \\
\hline \multirow[t]{2}{*}{ highETR } & -0.016 & $0.054^{\star *}$ \\
\hline & $(-0.65)$ & $(2.45)$ \\
\hline \multirow[t]{2}{*}{ lowETR } & $-0.046^{\star}$ & -0.020 \\
\hline & $(-1.83)$ & $(-0.90)$ \\
\hline \multirow[t]{2}{*}{ size } & 0.008 & -0.001 \\
\hline & $(1.01)$ & $(-0.07)$ \\
\hline \multirow[t]{2}{*}{ leverage } & -0.065 & 0.049 \\
\hline & $(-0.69)$ & $(0.57)$ \\
\hline \multirow[t]{2}{*}{ dsales } & $0.104^{*}$ & -0.033 \\
\hline & $(1.89)$ & $(-0.58)$ \\
\hline \multirow[t]{2}{*}{$\mathrm{dROA}$} & $-1.769^{* * *}$ & -0.356 \\
\hline & $(-3.68)$ & $(-1.00)$ \\
\hline \multirow[t]{2}{*}{ ownership } & $0.084^{\star * *}$ & $0.070^{* * *}$ \\
\hline & $(3.60)$ & $(3.61)$ \\
\hline \multirow[t]{2}{*}{ duality } & $0.072^{\star \star}$ & $0.049^{*}$ \\
\hline & $(2.51)$ & $(1.89)$ \\
\hline \multirow[t]{2}{*}{ meat_beat } & -0.000 & $-0.039^{\star}$ \\
\hline & $(-0.02)$ & $(-1.69)$ \\
\hline \multirow[t]{2}{*}{ _cons } & -0.170 & 0.011 \\
\hline & $(-0.97)$ & $(0.06)$ \\
\hline $\mathrm{N}$ & 1437 & 1481 \\
\hline
\end{tabular}

t statistics in parentheses: “* $p<0.1 ;{ }^{* *} p<0.05 ;{ }^{* * *} p<0.01$ ”.

listed companies is more intense, and tax avoidance can be used as a measure to enhance the competitiveness of listed companies. While passive tax avoidance will lead to the decline of competitiveness of enterprises, enterprises will take measures to replace incompetent executives. This result provides extra evidence for Liu \& $\mathrm{Lv}$ (2018)'s view on corporate tax avoidance to enhance corporate competitiveness.

\section{Robustness Check}

\section{1) Endogenous problems-Exogenous shock}

There may be endogenous problems caused by missing variables and reverse causality in this paper. For this reason, this paper uses the first-order lag executive turnover as the explained variable, which alleviates the endogenous problems caused by reverse causality to some extent. For the endogenous problem caused by missing variables, this paper introduces exogenous shocks. 
Table 8. Moderating effect of product market centralization.

\begin{tabular}{|c|c|c|}
\hline & Regression Results & \\
\hline & High centralization & Low centralization \\
\hline & f_CEO_fturnover & f_CEO_fturnover \\
\hline \multirow[t]{2}{*}{ highETR } & $0.152^{\star}$ & $0.226^{* *}$ \\
\hline & $(1.65)$ & $(2.07)$ \\
\hline \multirow[t]{2}{*}{ lowETR } & 0.006 & -0.132 \\
\hline & $(0.06)$ & $(-1.17)$ \\
\hline \multirow[t]{2}{*}{ size } & $-0.048^{\star}$ & 0.033 \\
\hline & $(-1.65)$ & $(0.95)$ \\
\hline \multirow[t]{2}{*}{ leverage } & $0.804^{\star *}$ & $-0.879^{* *}$ \\
\hline & $(2.37)$ & $(-2.04)$ \\
\hline \multirow[t]{2}{*}{ dsales } & 0.016 & $-0.374^{* *}$ \\
\hline & $(0.10)$ & $(-2.07)$ \\
\hline \multirow[t]{2}{*}{ dROA } & -0.455 & 0.089 \\
\hline & $(-1.25)$ & $(0.27)$ \\
\hline \multirow[t]{2}{*}{ ownership } & $0.415^{\star * *}$ & $0.555^{\star * *}$ \\
\hline & $(5.50)$ & $(6.99)$ \\
\hline \multirow[t]{2}{*}{ duality } & $0.430^{* * *}$ & $0.743^{\star * *}$ \\
\hline & $(4.33)$ & $(7.00)$ \\
\hline \multirow[t]{2}{*}{ meat_beat } & $-0.253^{* * *}$ & -0.109 \\
\hline & $(-3.16)$ & $(-1.23)$ \\
\hline Industry & Control & Control \\
\hline Year & Control & Control \\
\hline \multirow[t]{2}{*}{ _cons } & $-1.918^{* * *}$ & $-4.203^{* * *}$ \\
\hline & $(-2.86)$ & $(-5.39)$ \\
\hline $\mathrm{N}$ & 6982 & 6910 \\
\hline
\end{tabular}

t statistics in parentheses: “* $p<0.1 ;{ }^{* *} p<0.05 ;{ }^{* * *} p<0.01$ ".

In order to distinguish the impact of aggressive tax avoidance and passive tax avoidance on executive turnover, this paper divides the sample into two parts. When the ETR is greater than the mean value of the industry-year, then classify the sample as passive tax avoidance, leaving 5987 observations; otherwise categorize as aggressive tax avoidance sample, leaving 5899 observations.

For the turnover of executives caused by aggressive tax avoidance, this paper chooses the corporate income tax reform as its exogenous impact. Since the new corporate income tax law was formally implemented on January 1, 2008, bring- 
ing corporate income tax into the legal scope means that China's strengthened collection and management of corporate income tax, which will affect the tax avoidance motivation of enterprises. For executives' turnover, the corporate income tax reform is an exogenous shock. With the strengthening of tax collection and management, the aggressive tax avoidance behavior of enterprises is more likely to be concerned by public, which leads to more agency problems and reputation losses. Therefore, the 2008 corporate income tax reform will strengthen the impact of aggressive tax avoidance behavior on the forced turnover of executives. This paper sets the variable of TAXLAW to measure the corporate income tax reform. Since the corporate income tax law was implemented on January 1, 2008 , when the year $\geq 2008$, TAXLAW takes 1 ; otherwise, it takes 0 . In this paper, TAXLAW and its interaction with lowETR are introduced into the regression model. According to the results of Table 9, the coefficient of lowETR * TAXLAW is significantly positive at the $5 \%$ confidence level, which confirms the conjecture of this paper, indicating that the implement of the new corporate income tax law strengthens the impact of aggressive tax avoidance on executive turnover.

For the executive turnover caused by passive tax avoidance, this paper chooses the delisting mechanisms reform as an exogenous shock. In March 2012, the State Council transferred the notice of "opinions on deepening the key work of economic system reform in 2012" to the Development and Reform Commission, proposing to deepen the reform of financial system, improve the system of issuing new shares and delisting, and strengthen the protection of investors. In April of the same year, Shenzhen Stock Exchange issued the listing system of Gem shares of Shenzhen Stock Exchange (revised in 2012), and the delisting system of Gem was officially introduced. In November of the same year, Shanghai Stock Exchange issued three supporting business guidelines for delisting system. The delisting system increases the requirements for the performance indicators of listed companies, and carries out delisting risk warning, suspension or termination of listing for listed companies that fail to meet the corresponding performance indicators. Under the pressure of delisting, corporate executives have greater motivation to improve corporate performance through tax avoidance. Therefore, after the reform of delisting system, executives conducting passive tax avoidance are more likely to be replaced. This paper sets EXIT as the proxy of delisting system implementation. Since delisting system was introduced in 2012, when the year is after 2012, EXIT $=1$; otherwise, EXIT $=0$. This paper puts EXIT and its interaction with highETR into the model and carries out logit regression again. According to the results in Table 10, the coefficient of highETR * EXIT is significantly positive at the level of $1 \%$, which indicates that the introduction of delisting system has brought performance pressure to listed companies and prompted listed companies to replace executives who conduct passive tax avoidance.

In conclusion, after considering the endogenous problems caused by missing variables and reverse causality, the conclusion of this paper is still valid. 
Table 9. Regression results of exogenous shock-aggressive tax avoidance.

\begin{tabular}{|c|c|}
\hline \multicolumn{2}{|c|}{ Regression Results } \\
\hline & f_CEO_fturnover \\
\hline \multirow[t]{2}{*}{ lowETR } & -0.312 \\
\hline & $(-1.41)$ \\
\hline \multirow[t]{2}{*}{ TAXLAW } & $1.519^{* *}$ \\
\hline & $(2.05)$ \\
\hline \multirow[t]{2}{*}{ lowETR*TAXLAW } & $0.505^{* *}$ \\
\hline & $(2.15)$ \\
\hline \multirow[t]{2}{*}{ size } & 0.036 \\
\hline & $(0.96)$ \\
\hline \multirow[t]{2}{*}{ leverage } & 0.121 \\
\hline & $(0.27)$ \\
\hline \multirow[t]{2}{*}{ dsales } & 0.028 \\
\hline & $(0.10)$ \\
\hline \multirow[t]{2}{*}{ dROA } & -0.012 \\
\hline & $(-0.05)$ \\
\hline \multirow[t]{2}{*}{ ownership } & $0.678^{* * *}$ \\
\hline & $(7.14)$ \\
\hline \multirow[t]{2}{*}{ duality } & $0.611^{* * *}$ \\
\hline & $(5.02)$ \\
\hline \multirow[t]{2}{*}{ meat_beat } & $-0.260^{\star * *}$ \\
\hline & $(-2.73)$ \\
\hline Industry & Control \\
\hline Year & Control \\
\hline \multirow[t]{2}{*}{ _cons } & $-4.849^{\star * *}$ \\
\hline & $(-4.36)$ \\
\hline $\mathrm{N}$ & 5987 \\
\hline
\end{tabular}

t statistics in parentheses: ${ }^{*} p<0.1,{ }^{* *} p<0.05 ;{ }^{* *} p<0.01$.

\section{2) Substitution variables}

In order to make the results more robust, this paper substitutes the proxy variable of the degree of tax avoidance for the difference between the effective tax rate and the nominal tax rate and cash payment of the effective tax rate, and takes logit regression for the corresponding variables. The results show that the effective tax rate of cash payment only has the effect of cash flow, that is, only passive tax avoidance will executives forced turnover. However, aggressive tax avoidance has no significant effect on the forced turnover of executives of listed companies. Consistent with the result of Hypothesis 2, the possible explanation is that the agency cost caused by tax avoidance is less than the benefit brought by tax avoidance in the Chinese market, and the reputation cost in Chinese listed companies didn't play a good role in corporate governance in the aspect of tax avoidance. 
Table 10. Regression results of exogenous shock-passive tax avoidance.

\begin{tabular}{|c|c|}
\hline \multicolumn{2}{|c|}{ Regression Results } \\
\hline & f_CEO_fturnover \\
\hline \multirow[t]{2}{*}{ highETR } & -0.047 \\
\hline & $(-0.43)$ \\
\hline \multirow[t]{2}{*}{ EXIT } & $1.302^{\star \star}$ \\
\hline & $(2.37)$ \\
\hline \multirow[t]{2}{*}{ highETREXIT } & $0.348^{\star *}$ \\
\hline & $(2.33)$ \\
\hline \multirow[t]{2}{*}{ size } & 0.033 \\
\hline & $(0.93)$ \\
\hline \multirow[t]{2}{*}{ leverage } & -0.195 \\
\hline & $(-0.45)$ \\
\hline \multirow[t]{2}{*}{ dsales } & -0.032 \\
\hline & $(-0.13)$ \\
\hline \multirow[t]{2}{*}{$\mathrm{dROA}$} & $-2.588^{*}$ \\
\hline & $(-1.66)$ \\
\hline \multirow[t]{2}{*}{ ownership } & $0.411^{* * *}$ \\
\hline & $(4.72)$ \\
\hline \multirow[t]{2}{*}{ duality } & $0.573^{* * *}$ \\
\hline & $(4.87)$ \\
\hline \multirow[t]{2}{*}{ meat_beat } & 0.030 \\
\hline & $(0.31)$ \\
\hline Industry & Control \\
\hline Year & Control \\
\hline \multirow[t]{2}{*}{ _cons } & $-4.703^{\star * *}$ \\
\hline & $(-4.85)$ \\
\hline $\mathrm{N}$ & 5899 \\
\hline
\end{tabular}

t statistics in parentheses: “* $p<0.1,{ }^{* *} p<0.05,{ }^{* * *} p<0.01$ ”.

\section{Summary}

\subsection{Conclusion}

Based on the data of A-share listed companies in 2004-2018, this paper discusses the economic consequences of corporate tax avoidance from the perspective of senior executives.

First, both aggressive tax avoidance and passive tax avoidance will increase the risk of executives forced to be replaced;

Secondly, the passive tax avoidance behavior increases the risk of executives forced to be replaced by damaging the short-term performance of the enterprise 
and arousing the concern of shareholders about their efforts. Aggressive tax avoidance will damage the reputation of senior executives, which lead to the forced turnover of senior executives under the role of reputation mechanism;

Third, from the perspective of different property rights, this paper finds that in private enterprises, the passive tax avoidance behavior of enterprises is more likely to lead to the forced turnover of executives of listed companies, while the state-owned enterprises are less likely to do so, which may be due to the political background of state-owned enterprises and the complex and diverse assessment standards for executives, weakening the impact of corporate tax avoidance on the replacement of executives;

Fourthly, from the perspective of the performance of different corporate social responsibilities, this paper finds that the performance of corporate social responsibilities can reduce the impact of passive tax avoidance on the mandatory replacement of executives in listed companies, which shows that the performance of corporate social responsibilities improves the image of executives in the minds of shareholders;

Fifthly, from the perspective of different market concentration, this paper finds that executives under low market concentration are more likely to be replaced with passive tax avoidance behavior. The possible explanation is that corporate tax avoidance, as a measure to enhance competitiveness, can help enterprises gain market in fierce market competition. Therefore, executives with passive tax avoidance are more likely to be forcibly replaced by enterprises for strategic considerations.

\subsection{Contributions and Limitations}

From the perspective of senior executives, this paper studies the economic consequences of tax avoidance, with the following contributions:

Firstly, from the existing research on corporate tax avoidance, most of the research focuses on whether the corporate tax avoidance can alleviate the financing pressure and enhance the corporate value. Few researches divide the degree of corporate tax avoidance into aggressive tax avoidance, reasonable tax avoidance and passive tax avoidance, and discuss the impact of different tax avoidance behavior on micro corporate behavior and economic consequences. This paper discusses the impact of tax avoidance on executive turnover from the perspectives of aggressive tax avoidance and passive tax avoidance, and finds that the impact of corporate tax avoidance on executive turnover is non-linear. Both aggressive tax avoidance and passive tax avoidance can lead to executive forced turnover.

Secondly, most of the studies focus on the economic consequences of tax avoidance on the whole of the enterprise, while few of them focus on the impact on the individual level of executives. This paper chooses the perspective of senior executives to study whether tax avoidance will lead to the forced turnover of senior executives, so as to provide a perspective related to senior executives in tax avoidance, so that senior executives can make economic decisions that are most suitable for enterprises and their own career development. 
Finally, in the study of whether corporate tax avoidance brings reputation cost so far, Gallemore only found that corporate tax avoidance will lead to short-term fluctuations in the stock market, but no evidence of other reputation cost. Although he later concluded that corporate tax avoidance will bring reputation loss to executives through case analysis, up to now, no empirical evidence has been found. Through empirical research, this paper finds that the aggressive tax avoidance behavior of the enterprise will cause the executives to be forced replaced, which is the embodiment of reputational cost of tax avoidance.

There are also some research limitations in this study Due to the limitation of information disclosure, it is difficult to distinguish whether the turnover of executives in listed companies is abnormal or not, such as "other", which has caused some trouble to the research of this paper, but after considering it as normal replacement, the conclusion of this paper is still valid, so the conclusion of this paper is relatively stable in this respect.

\subsection{Suggestions}

China's capital market and financial market have been basically formed after 40 years of establishment, but compared with the developed countries in Europe and America, they are still lagging behind, resulting in the development of China's listed companies, especially small and medium-sized enterprises, is still hindered by financing constraints. That is exactly one of the main reasons for China's listed companies to conduct tax avoidance behavior. Although corporate tax avoidance can bring short-term economic benefits to listed companies, it is harmful to the long-term development of enterprises. At the same time, the existence of corporate tax avoidance increases the enforcement of tax regulatory agencies, which will cause a waste of national resources. Therefore, in order to reduce the impact of corporate tax avoidance on listed companies and their management, we must explore solutions from the source. The government needs to strengthen the construction of financial system, deepen the innovation of financial system, improve financial services, and dredge the channels for finance to enter the real economy, especially for small and medium-sized enterprises, so as to solve the financing problems of listed companies. In the market of capital security and full circulation, the motivation of enterprises to avoid tax will not be that strong, and the microeconomic consequences of enterprises which undertake tax avoidance will also be greatly mitigated.

\section{Conflicts of Interest}

The author declares no conflicts of interest regarding the publication of this paper.

\section{References}

Chen, K. P., \& Chu, C. Y. C. (2005). Internal Control versus External Manipulation: A Model of Corporate Income Tax Evasion. The RAND Journal of Economics, 36, 151-164.

Desai, M. A. \& Dharmapala, D. (2005). Corporate Tax Avoidance and High-Powered In- 
centives. Journal of Financial Economics, 79, Article No. 11241.

https://doi.org/10.3386/w11241

Gallemore, J., Maydew, E. L., \& Thornock, J. R. (2014). The Reputational Costs of Tax Avoidance. Contemporary Accounting Research, 31, 1103-1133. https://doi.org/10.1111/1911-3846.12055

Graham, J. R., Hanlon, M., Shevlin, T., \& Shroff, N. (2017). Tax Rates and Corporate Decision-Making. Review of Financial Studies, 30, 3128-3175. https://doi.org/10.1093/rfs/hhx037

Hanlon, M., \& Heitzman, S. (2010) A Review of Tax Research. Journal of Accounting and Economics, 50, 127-178. https://doi.org/10.1016/j.jacceco.2010.09.002

Liu, H., \& Lv, C. J. (2018). Strategic Effect of Tax Avoidance: The Causal Impact of Tax Avoidance on Firms' Product Market Performance. Journal of Financial Research, 7, 158-173.

Wang, D. Z., \& Luo, M. L. (2017). Tax Avoidance, Social Responsibility Commitment and Firm Value. Communication of Finance and Accounting, 15, 31-35+12.

Wilson, R. J. (2009). An Examination of Corporate Tax Shelter Participants. The Accounting Review, 84, 969-999. https://doi.org/10.2308/accr.2009.84.3.969

Ye, K. T. \& Liu, H. (2014). Corporate Tax Avoidance and Internal Agency Costs. Journal of Financial Research, 9, 158-176.

Zhang, M. H., Zhang, H. F., \& Zhang, R. (2018). The Heterogeneous Influence of Financing Constraints on Tax Avoidance Behavior of Enterprises: Evidence from Listed Companies. Tax Research, 1, 93-99. 